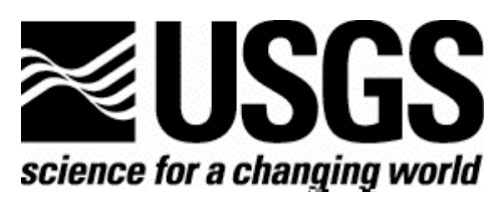

\title{
Documentation for 2003 USGS Seismic Hazard Maps for Puerto Rico and the U.S. Virgin Islands
}

By C.S. Mueller, A.D. Frankel, M.D. Petersen, and E.V. Leyendecker

Any use of trade, firm, or product names is for descriptive purposes only and does not imply endorsement by the U.S. Government

Open-File Report 03-379

U.S. Department of the Interior

U.S. Geological Survey 


\title{
U.S. Department of the Interior
}

Gale A. Norton, Secretary

\section{U.S. Geological Survey \\ Charles G. Groat, Director}

\author{
U.S. Geological Survey, Reston, Virginia 2004
}

For product and ordering information:

World Wide Web: http://www.usgs.gov/pubprod

Telephone: 1-888-ASK-USGS

For more information on the USGS - the Federal source for science about the Earth, its natural and living resources, natural hazards, and the environment:

World Wide Web: http://www.usgs.gov

Telephone: 1-888-ASK-USGS 


\section{Contents}

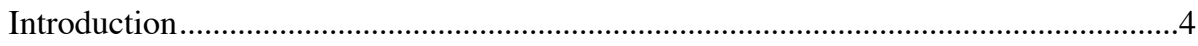

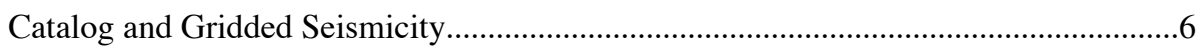

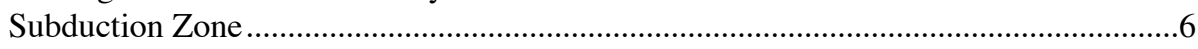

Mona Passage and Anegada Passage Extensional Zones..............................................

Eastern Seprentrional fault and South Puerto Rico Slope fault ...................................

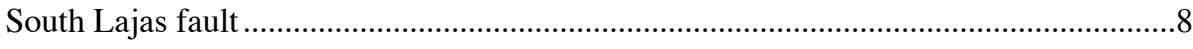

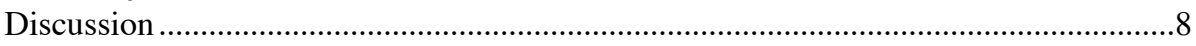

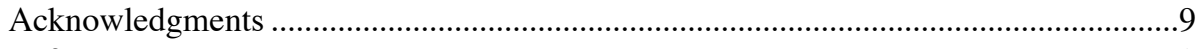

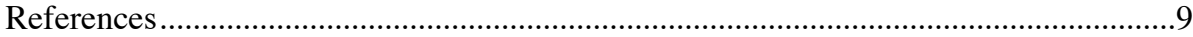




\title{
Documentation for 2003 USGS Seismic Hazard Maps for Puerto Rico and the U.S. Virgin Islands
}

\author{
By C.S. Mueller, A.D. Frankel, M.D. Petersen, and E.V. Leyendecker
}

\section{Introduction}

We present results of a new probabilistic seismic hazard assessment for Puerto Rico and the U. S. Virgin Islands (PRVI). The study area (Fig. 1) is located along the boundary between the northeastern Caribbean Sea and the Atlantic Ocean, at the intersection of the Greater and Lesser Antilles Island chains. These islands demarcate the boundary between the North American and Caribbean tectonic plates, with the North American plate moving westsouthwestward relative to the Caribbean plate at a rate determined from GPS geodesy of $19.4 \mathrm{~mm} / \mathrm{yr}$ (Jansma and others, 2000). West of PRVI the two plates move along typical transform structures (the east-west-striking, leftlateral Oriente and Enriquillo - Plantain Garden faults, and related structures). Southeast of PRVI the North American plate subducts westward beneath the Caribbean plate, forming a typical volcanic island arc (the northsouth-trending Lesser Antilles). Plate interaction near PRVI, in contrast, occurs in a 250-kilometer-wide, east-westtrending zone of complex transpressional deformation, delimited by the Puerto Rico Trench in the north and the Muertos Trough in the south. Puerto Rico and the Virgin Islands lie on a shallow submarine bank within this complex deformational zone.

The region is home to approximately four million United States citizens, and has a long history of destructive earthquakes. Historical records show that major earthquakes have struck PRVI several times during the past 500 years, although the locations and sizes of events that have occurred more than a few decades ago are poorly known. Major earthquakes have damaged Puerto Rico in 1520, 1615, 1751, 1776, 1787 (magnitude 8.0, thought to have ruptured the plate interface south of the Puerto Rico Trench, offshore northern Puerto Rico), 1867 ( 7.3, Anegada Passage, offshore southeastern Puerto Rico), 1918 ( 7.5, Mona Passage, offshore northwestern Puerto Rico), 1943 ( 7.7, plate interface, offshore northwestern Puerto Rico), and 1946 ( 8.0, plate interface, northeastern Hispaniola) (e.g., McCann, 1985; Dolan and Wald, 1998). The 1867 and 1918 earthquakes were accompanied by destructive tsunamis.

Seismicity near PRVI is primarily related to: 1) highly oblique subduction of the North American plate beneath the terranes of the plate boundary zone along the main plate interface south of the Puerto Rico Trench, and 2) the interactions of several probable microplates within the complex boundary zone. Geodesy and seismicity data suggest the existence of a Puerto Rico - northern Virgin Islands microplate that is relatively rigid and seismically quiescent internally (Masson and Scanlon, 1991; Jansma and others, 2000). Most of the major seismogenic sources are concentrated offshore; thus, estimates of activity rates on specific structures can be highly uncertain, often based on indirect evidence such as seismicity patterns and focal mechanisms, bathymetry and shallow seafloor seismic imagery, regional geodesy, kinematic reasoning, and tectonic analogs. The Great Northern and Great Southern Puerto Rico faults, major left-lateral strike-slip systems active on Puerto Rico from the early Cretaceous to the early Miocene are now considered largely quiescent, although they seem to be associated with very small earthquakes, and may represent inherited zones of weakness (McCann, 1985). Prentice and others (2000) have determined a recurrence rate for one fault onshore southwestern Puerto Rico that they consider to be currently active; several other candidate faults have been identified in western Puerto Rico, but not yet evaluated paleoseismically.

Seismic sources related to deformation along the main plate boundary include megathrust faulting along the plate interface, southward-deepening intraslab faulting within the subducting North American plate, and strike-slip faulting along several structures that strike subparallel to the Puerto Rico trench north and northwest of Puerto Rico (Fig. 1). These include the Septentrional fault, the major plate boundary structure in central Hispaniola, which extends eastward across the northern Mona Passage toward Puerto Rico, and the so-called North and South Puerto Rico Slope fault zones and related structures. Sources related to microplate interactions include two broad zones of 
roughly east-west tectonic extension, one west of Puerto Rico roughly coincident with the Mona Passage, and one southeast of Puerto Rico roughly coincident with the Anegada Passage. Extension within these zones is thought to be related to differences in rates of eastward motion (relative to North America) of crustal blocks south of the main plate boundary (e.g., McCann and others, 1987; Jansma and others, 2000): the Caribbean plate moves eastward relatively unrestricted, while blocks within the boundary zone are restricted by relatively high-standing tectonic features like the Bahama Bank and Main Ridge (Fig. 1). As discussed above, we include one terrestrial fault, the South Lajas fault onshore southwestern Puerto Rico (Prentice and others, 2000), in the hazard model.

We apply the probabilistic hazard methodology developed by the U. S. Geological Survey (USGS) as described by Frankel and others $(1996,2002)$, and present maps of probabilistic motions: peak ground acceleration (pga), 1.0-second spectral response, and 0.2 -second spectral response, with $2 \%$ and $10 \%$ probability of exceedance in 50 years, corresponding to return times of approximately 2500 and 500 years, respectively. Like others in the USGS seismic hazard series, these maps will be used in earthquake mitigation and response planning, and derived engineering-design-motion maps will be considered for adoption in future updates of building codes and other structural design standards (Leyendecker and others, 2000). The USGS methodology is based primarily on 1) gridded and smoothed historical seismicity, generalized using exponential magnitude distributions with regionally determined $b$ values, and 2) specific fault sources with published slip-rate or recurrence information. Where there is reason to suspect that the seismicity or fault components of the model are incomplete, they can be supplemented with sources based on geodetic or other deformation data. Earthquakes are assumed to occur randomly in time; the probabilistic ground motions represent time-independent seismic hazard.

Specific components of the PRVI hazard model (Fig. 2) include: gridded and smoothed historical seismicity (moment magnitude greater than or equal to 4.5, 1963-2001) divided into four depth ranges, megathrust faulting along the main subduction interface south of the Puerto Rico trench, Mona Passage and Anegada Passage extensional zones with seismic activity rates determined from GPS geodesy, the Septentrional fault, the South Puerto Rico Slope fault, and the South Lajas fault. Because some sources overlap spatially, magnitude ranges in the model are adjusted to avoid double counting hazard contributions. Like LaForge and McCann (2003), we exclude the North Puerto Rico Slope fault zone from our model because it is located more than $100 \mathrm{~km}$ from the north shore of Puerto Rico and only a few kilometers south of the deformation front of the south-dipping Puerto Rico Trench (Fig. 1) subduction interface (also Dolan and Wald, 1998). We exclude the Muertos Trough (Fig. 1) and related structures offshore southern Puerto Rico from our model because their rates of activity are very poorly known. (We note that LaForge and McCann, who include these structures in their model, suggest that rates of activity on these structures must be low in comparison with other model components, and agree with them that their proximity to the south coast of Puerto Rico makes them important targets for future research.)

Alternative ground-motion-prediction relations for a uniform NEHRP B/C-boundary $\left(\mathrm{V}_{\mathrm{s}} 30=760 \mathrm{~m} / \mathrm{s}\right)$ site condition are included using a logic-tree formalism. For the shallow-seismicity, extensional-zone, and crustal-fault sources, we use a mix of relations for crustal earthquakes derived from western North American and worldwide data. For the deep-seismicity and subduction sources, we use a mix of intraslab and interplate relations, respectively, derived from worldwide data. (Specific ground-motion relations are discussed below for each hazard-model element.) A new ground-motion relation recently developed from Caribbean data by Motazedian and Atkinson (2003) (M\&A) is included for the shallow-seismicity, extensional-zone, and crustal-fault sources. (Roughly 2/3 of the earthquakes in their dataset are shallower then $50 \mathrm{~km}$; they do not distinguish between shallow and deep seismicity in their relation, but we use it for crustal sources only.) We adjust their relation for NEHRP B/Cboundary site conditions using factors calculated from equations in Boore and others (1997). Geologically, one might expect ground motion attenuation to be lower in PRVI than in western North America, but we are concerned that high-frequency ground motions from the new relation are much higher than those from comparable western North American relations (see the Discussion below). Pending further evaluation of the new M\&A relation, it receives roughly one half the weight given to more established relations in the ground-motion-relation logic tree.

With a site grid spacing of 0.05 degree in latitude and longitude, we compute hazard curves for approximately 16000 sites within the area mapped in Figure 2. 


\section{Catalog and Gridded Seismicity}

A uniform seismicity catalog is constructed from four source catalogs: 1) a compilation by Engdahl and Villasenor of large, carefully relocated global earthquakes (called EV here, downloaded from ftp site ciei.colorado.edu/pub/user/engdahl/Handbook/CENT.CAT), 2) the International Seismological Centre global catalog (ISC, downloaded from the USGS National Earthquake Information Center), 3) the USGS Preliminary Determination of Epicenters global catalog (PDE, downloaded from the USGS National Earthquake Information Center), and 4) the Panamerican Institute of Geology and History catalog (IPGH, downloaded from the web site of the Middle America Seismograph Consortium: midas.upr.clu.edu/mds-ipgh.html). Aware of well-documented past problems with magnitude determinations (e.g., LaForge and McCann, 2003), we choose not to include data from the local Puerto Rico Seismic Network catalog. The four source catalogs are reformatted, concatenated, and chronologically sorted. We remove duplicates and dependent events generally following the approach described by Mueller and others (1997): duplicates are removed using the above order of source-catalog preference, and aftershocks and foreshocks are removed (in order to insure the statistical independence of the earthquakes used in the hazard analysis) using the algorithm of Gardner and Knopoff (1974). Our final PRVI catalog is judged to be complete down to moment magnitude 4.5 from 1963 to 2001, and contains 15 EV events, 354 ISC events, 137 PDE events, and 20 IPGH events.

The catalog is divided into four subcatalogs by depth: $0-50 \mathrm{~km}, 50-80,80-120$, and greater than 120 . Spatial relationships of the deeper-than-50-km hypocenters suggest that these earthquakes are primarily associated with (located within) the southward-subducting North American plate. The seismicity data, both shallow and deep, are consistent with a $b$ value of 1.0 (which is subsequently applied for all hazard model elements). $10^{\text {a }}$-value grids are computed for each subcatalog (Weichert, 1980) and spatially smoothed (using a two-dimensional Gaussian function with a 50-km correlation distance for the 0-50-km-deep seismicity, and a 30-km Gaussian for the deeper seismicity). These grids are used to compute the hazard contribution from seismicity for distance range 0 to $200 \mathrm{~km}$ and moment-magnitude range 5.0 to 7.0. (For grid cells that fall within the Mona and Anegada extensional zones, the maximum magnitude for the $0-50-\mathrm{km}$ seismicity is reduced from 7.0 to 6.5 to avoid overlapping hazard contributions - see below.) For the 0-50-km seismicity we use the new M\&A ground-motion relation plus four wellestablished relations for shallow crustal earthquakes with coefficients for reverse-oblique (or averaged reverse-slip / strike-slip) faulting: Boore and others (1997) for $\mathrm{V}_{\mathrm{S}} 30=760 \mathrm{~m} / \mathrm{s}$, Sadigh and others (1997) for rock, Campbell and Bozorgnia (2003) adjusted for $\mathrm{V}_{\mathrm{s}} 30=760 \mathrm{~m} / \mathrm{s}$, and Abrahamson and Silva (1997) for rock. The latter four relations were used for the non-extensional western US in the 2002 update of the USGS national hazard maps (Frankel and others, 2002). M\&A receives $10 \%$ weight and each of the other four $22.5 \%$ in the ground-motion-relation logic tree. For seismicity deeper than $50 \mathrm{~km}$ we use two intraplate ground-motion relations: Youngs and others (1997) and Atkinson and Boore (2003) - each with equal 50\% weight. Maps of probabilistic pga for the shallow and deep seismicity models are shown in Figures $3 \mathrm{a}$ and $\underline{3 b}$, respectively.

\section{Subduction Zone}

We subdivide the subduction interface south of the Puerto Rico trench into Puerto Rico and Hispaniola segments (Fig. 2), generally following published ideas about tectonic segmentation, the estimated sizes of past megathrust earthquakes, and regional variations in seismic coupling along the thrust interface (e.g., Frankel and others, 1980; Dolan and Wald, 1998; LaForge and McCann, 2003). Thrust interface earthquakes on the Puerto Rico segment are modeled as characteristic floating magnitude-7.9 ruptures with 190-year recurrence times, corresponding to approximately $20 \%$ seismic coupling for a GPS-determined slip rate of $16.9 \mathrm{~mm} / \mathrm{yr}$ between North America and PRVI (Jansma and others, 2000). Thrust interface earthquakes on the Hispaniola segment are modeled as characteristic floating magnitude-8.0 ruptures with 200 -year recurrence times, corresponding to approximately 80\% seismic coupling. Historically, the 1943 northern Mona Passage and 1946 northeastern Hispaniola earthquakes ruptured the Puerto Rico and Hispaniola subduction segments, respectively (Dolan and Wald, 1998), and the great earthquake of 1787 probably ruptured the Puerto Rico subduction segment (McCann, 1985). Locations of the updip and downdip edges of the rupture zones correspond to plate-top depths of 10 and $40 \mathrm{~km}$, respectively. We apply two ground-motion relations for the subduction models: Youngs and others (1997) and Sadigh and others (1997), each with $50 \%$ weight out to a crossover distance $(58 \mathrm{~km})$, beyond which the Youngs relation receives full weight. The 
Sadigh relation, developed from crustal earthquake data, offsets a tendency for relations based on the empirical interface-earthquake dataset alone to underpredict ground motions at short distances from simulated large thrust events (Youngs and others, 1997). Maps of probabilistic pga for the two subduction models are shown in Figures $3 \mathrm{c}$ and $\underline{3 \mathrm{~d}}$.

\section{Mona Passage and Anegada Passage Extensional Zones}

The Mona Passage between Puerto Rico and Hispaniola coincides with a broad zone of active crustal extension. Bathymetry, subsea seismic imaging, and focal-mechanism data are all suggestive of normal faulting on generally north-south trending structures and east-west-directed extension. One of the largest bathymetric features in the Passage, the north-south-trending Mona Canyon, is thought to be normal-fault controlled, and was probably the site (Mercado and McCann, 1998) of a magnitude 7.5, tsunamigenic earthquake in 1918 that damaged northwestern Puerto Rico with large losses of life and property (LaForge and McCann, 2003). We assign a rate of east-west extension of $5 \mathrm{~mm} / \mathrm{yr}$ based on recent GPS geodesy results (Jansma and others, 2000), assume a $b$ value of 1.0, and prorate faulting uniformly into each grid cell in the zone, using the method described by Frankel and others (1996) for computing hazard from areal zones. The corresponding $10^{\mathrm{a}}$-value grids are smoothed using a two-dimensional Gaussian function with a 20-km correlation distance, eliminating the sharp zone boundary. The zone shape (Fig. 2) is similar to that suggested by McCann (1998). It also accounts for increased seismicity in southwestern Puerto Rico that is seen in some maps of small earthquakes (e.g., LaForge and McCann, 2003), but not reflected in our catalog. Hazard is computed for the distance range 0 to $200 \mathrm{~km}$ and moment-magnitude range 6.5 to 7.5 . (For grid cells that fall within 10 kilometers of the trace of the South Lajas fault, the maximum magnitude is reduced from 7.5 to 7.0 to avoid overlapping hazard contributions - see below.) The model predicts the occurrence of a moment-magnitude6.5 -or-greater earthquake in the zone about every 50 years; our catalog contains two $\mathrm{M}=6.5$-or-greater earthquakes and nine $\mathrm{M}=6.0$-or-greater earthquakes since 1860, including the $\mathrm{M} \sim 7.5$ event of 1918. Ground-motions are computed with the same group of five relations used above for shallow seismicity, using coefficients for strike-slip faulting, and adding a relation from Spudich and others (1999) for extensional tectonic regimes. M\&A receives 10\% weight, and each of the other five $18 \%$ in the ground-motion-relation logic tree.

The east-northeast-striking Anegada Passage, offshore southeastern Puerto Rico, coincides with a series of fault-bounded basins and a zone of tectonic transtension where displacement from the eastern end of the Muertos trough is thought to be transferred to the Puerto Rico trench (e.g., Jansma and others, 2000). The extensional zone may have been initially formed during a previous episode or counterclockwise rotation of the PRVI microplate, but current tectonism is enigmatic, with negligible movement between GPS sites on St. Croix and Virgin Gorda constraining possible slip rates. The zone shape (Fig. 2) follows McCann (1993) as extended northeastward beyond the Virgin Islands (W. McCann, personal communication, 2003). Jansma and others propose that slip across the zone must be less than $2 \mathrm{~mm} / \mathrm{yr}$. LaForge and McCann (2003) use $2.4 \mathrm{~mm} / \mathrm{yr}$ for consistency with the rate assigned to the Muertos Trough system in their model. We assign $1 \mathrm{~mm} / \mathrm{yr}$ of east-west extension to the Anegada Passage zone. The model predicts the occurrence of a moment-magnitude-6.5-or-greater earthquake in the zone about every 300 years; historically, the $\mathrm{M} \sim 7.3$ earthquake of 1867 occurred in the Anegada Passage. The hazard analysis is similar to that described above for the Mona Passage extensional zone. A map of probabilistic pga for the Mona Passage and Anegada Passage models is shown in Figure 3e.

\section{Eastern Seprentrional fault and South Puerto Rico Slope fault}

The Septentrional fault system extends east-southeastward, subparallel to the Puerto Rico Trench, from northern Hispaniola toward Puerto Rico (Fig. 2). This transitional feature accommodates an increasing partition of left-lateral strike-slip motion with increasing distance west of PRVI, until it becomes the major plate boundary structure in central Hispaniola (e.g., Prentice and others, 1993, 2003) with upwards of $9 \mathrm{~mm} / \mathrm{yr}$ of slip. A major concern in assessing the seismic hazard of Puerto Rico is estimating the importance of the eastern reach of the Septentrional fault and its possible eastward extension across Mona Canyon, the South Puerto Rico Slope fault zone. Deformation at the longitude of Puerto Rico may be taken up along other strike-slip structures that lie farther north, closer to the Puerto Rico Trench, such as the Northeastern Hispaniola Slope fault and the North Puerto Rico Slope 
fault zone (Grindlay and others, 1997; Dolan and others, 1998; LaForge and McCann, 2003; U. ten Brink, personal communication, 2003), structures that do not pose a significant ground motion threat to Puerto Rico. Unfortunately, it is difficult to estimate the relative importance of these structures directly.

The eastern reach of the Septentrional fault apparently intersects Mona Canyon near 67.5 degrees west longitude, but does not offset the canyon, and its possible extension east of Mona Canyon is unknown. The 350-km total length of the fault correlates with magnitude 8.0, using the relations of Wells and Coppersmith (1994). Prentice and others (2003) find a slip rate of $9 \mathrm{~mm} / \mathrm{yr}$ in central Hispaniola from paleoseismic analysis. LaForge and McCann (2003) argue, however, that the slip rate and maximum magnitude must decrease along the eastern reach of the fault,

Table 1. Septentrional fault scenarios.

\begin{tabular}{|c|c|c|c|}
\hline Mom. mag & Slip rate(mm/yr) & Implied recurrence (yr) & comment \\
\hline 7.3 & 9 & 70 & too frequent \\
\hline 7.3 & 5 & 130 & too frequent \\
\hline 7.3 & 2 & 310 & OK? \\
\hline 8.0 & 9 & 770 & OK \\
\hline 8.0 & 5 & 1400 & OK \\
\hline 8.0 & 2 & 3600 & OK \\
\hline
\end{tabular}

and use a magnitude of 7.3 and a slip rate of $2 \mathrm{~mm} / \mathrm{yr}$ in their model. There are no direct estimates of the slip rate, and about the only constraint on the parameters required for the seismic hazard calculation is the observation that there have been no major earthquakes associated with the eastern Septentrional fault historically. In Table 1 we consider several "end member" rupture scenarios, and use this weak constraint to test their plausibility. Recurrence times implied by the two high-slip-rate, moment-magnitude-7.3 scenarios are too short; the surviving four scenarios are combined as characteristic ruptures in a logic tree with equal 0.25 weights. Ground-motions are computed with the same group of four relations used for shallow seismicity, using coefficients for strike-slip faulting.

Estimates of the slip rate on the South Puerto Rico Slope fault zone range from $9 \mathrm{~mm} / \mathrm{yr}$ (as the eastward extension of the Septentrional fault) to zero (the transverse component of deformation is fully accommodated along structures farther to the north). LaForge and McCann (2003) assign it a slip rate of $1 \mathrm{~mm} / \mathrm{yr}$ in their model, but note that it may be inactive. The $160-\mathrm{km}$ total length of the fault correlates with magnitude 7.6, using the relations of Wells and Coppersmith (1994). Following LaForge and McCann, we assign a slip rate of $1 \mathrm{~mm} / \mathrm{yr}$ (corresponding to a recurrence of 3900 years), and use the same suite of four ground motion relations that were used for the Septentrional fault. The sensitivity of probabilistic ground motions in Puerto Rico to the choice of slip rate on the South Puerto Rico Slope fault zone is discussed below.

\section{South Lajas fault}

Prentice and others (2000) have trenched the east-west-striking South Lajas fault in southwestern Puerto Rico, finding evidence for two surface-rupturing earthquakes in the last 7500 years. The $50-\mathrm{km}$ total length of the fault (LaForge and McCann, 2003) correlates with moment magnitude 7.0 using the relations of Wells and Coppersmith (1994). We include the fault in the hazard model as a characteristic earthquake with moment magnitude $=7.0$ and recurrence time $=3500$ years, using the same suite of four ground motion relations that were used for the Septentrional fault.

\section{Discussion}

Maps of probabilistic pga, 1.0-second spectral acceleration, and 0.2-second spectral acceleration, including the contributions from all modeled sources, for a probability of exceedance of $2 \%$ in 50 years (approximately 2500 year return time) are shown in Figs. $4, \underline{5}$, and $\underline{6}$, respectively. Corresponding maps for an exceedance probability of $10 \%$ in 50 years (approximately 500-year return time) are shown in Figures $7, \underline{8}$, and $\underline{9}$. 
The range of probabilistic ground motions for PRVI is roughly comparable to that found in the Basin and Range province of the western United States. LaForge and McCann (2003) conduct a seismic hazard analysis for sites at the four corners of the island of Puerto Rico. For western Puerto Rico our pga values agree with theirs to within 5-10\%. For eastern Puerto Rico our pga values are systematically 10-15\% greater than theirs. We note the strong clusters of seismicity near and north of the Virgin Islands (Figs. 3a,$\underline{b})$ that are strong contributors to the hazard in eastern Puerto Rico and the Virgin Islands in our model (see below), whereas background seismicity is distributed into a uniform areal zone in the LaForge and McCann approach. Additionally, we use a maximum moment-magnitude value of 7.0 for these sources, instead of their 6.5.

The sensitivity of our results to the choice of slip rate on the South Puerto Rico Slope fault zone is explored in Figure 10. The maps show probabilistic pga from all modeled sources, comparing 9-mm/yr (440-year recurrence) and 1-mm/yr (3900-year recurrence) characteristic scenarios for the SPRSFZ. Near the fault (upper-left corner of each map) there are significant pga differences, but closer sources dominate the hazard in Puerto Rico, and differences there are negligible (note, for example, the $50 \%$-g contour that cuts across the northwest coast of the island).

Figures 11 and $\underline{12}$ explore the sensitivity of our results to the choice of weight given to the Motazedian and Atkinson (2003) relation in the ground-motion relation logic tree. The maps show probabilistic 0.2-second (Fig.11) and 1.0-second (Fig.12) spectral acceleration from all modeled sources, comparing 50\% and 10\% weights for the M\&A relation. Figure 11 shows much larger 0.2 -second ground motions for $50 \%$ weight - as much as $60 \%$ larger in the southwestern corner of Puerto Rico where the hazard is dominated by the Mona Passage extensional zone and South Lajas fault sources (see below), both of which use the M\&A relation. From a geologic point of view, one might expect lower attenuation in PRVI than in tectonically active California, but concern over the very large highfrequency motions accounts for the low weight used for M\&A in the final hazard model - pending further evaluation of the relation. Figure 12 shows that 1.0 -second ground motion differences are small.

Figure 13 shows hazard curves with contributions from individual model elements for six sites. At San Juan (13a) for both $2 \%$ and $10 \%$ probability of exceedance in 50 years (PE50) shallow seismicity, deep seismicity, and the Puerto Rico segment subduction account, about equally, for essentially all the hazard. At Mayaguez ( $\underline{13 \mathrm{~b}})$ and Ponce $(13 \mathrm{c})$ the Mona Passage extensional zone dominates the hazard (increasingly at longer return times), with smaller contributions from shallow and deep seismicity. At Charlotte Amalie, St. Thomas ( $\underline{13 \mathrm{~d}})$, shallow and deep seismicity dominate the hazard, equally at 2\% PE50, with much smaller contributions from the Puerto Rico segment subduction and the Anegada Passage extensional zone. At Christiansted, St. Croix (13e), deep seismicity dominates the hazard (more so at 10\% PE50 than 2\% PE50), with smaller contributions from shallow seismicity and the Anegada extensional zone. Finally, Figure $13 \mathrm{f}$ shows pga hazard curves for a point in southwestern Puerto Rico near the South Lajas fault; its contribution equals that of the Mona Passage extensional zone for 2\% PE50, and dominates the hazard for longer return times, demonstrating the importance of targeting possible active onshore faults for future research.

\section{Acknowledgments}

We gratefully acknowledge discussions with Roland LaForge, Bill McCann, Carol Prentice, Christa von Hillebrandt, Gail Atkinson, Dariush Motazedian, Steve Harmsen, and C. B. Crouse. We received valuable input from participants of the workshop on seismic and tsunami hazards of Puerto Rico held in San Juan in March 1999, and feedback on a preliminary version of the hazard model from members of the TS-1 subcommittee of the Building Seismic Safety Commission chaired by C. B. Crouse. The figures in this paper were produced with the Generic Mapping Tools (GMT) software (Wessel and Smith, 1991).

\section{References}

Abrahamson, N.A., and W.J. Silva (1997). Empirical response spectral attenuation relations for shallow crustal earthquakes, Seism. Res. Letts., v. 68, 94-127. 
Atkinson, G.M., and D.M. Boore (2003). Empirical ground-motion relations for subduction zone earthquakes and their applications to Cascadia and other regions, Bull. Seism. Soc. Am. - in review.

Boore, D.M., W.B. Joyner, and T.E. Fumal (1997). Equations for estimating horizontal response spectra and peak acceleration from western North American earthquakes: a summary of recent work, Seism. Res. Letts., v. 68, 128-153.

Campbell, K.W., and Y. Bozorgnia (2003). Updated near-source ground motion (attenuation) relations for the horizontal and vertical components of peak ground acceleration and acceleration response spectra, Bull. Seism. Soc. Am. - in press.

Dolan, J.F., H. T. Mullins, and D.J. Wald (1998), Active tectonics of the north-central Caribbean: Oblique collision, strain partitioning, and opposing subducted slabs, in Dolan, J.F. and Mann, P., eds., Active Strike-Slip and Collisional Tectonics of the Northern Caribbean Plate Boundary Zone, Geological Society of America Special Paper 326, Boulder, Colorado, 161.

Dolan, J.F., and D.J. Wald (1998), The 1943-1953 north-central Caribbean earthquakes: Active tectonic setting, seismic hazards, and implications for Caribbean - North America plate motions, in Dolan, J.F. and Mann, P., eds., Active Strike-Slip and Collisional Tectonics of the Northern Caribbean Plate Boundary Zone, Geological Society of America Special Paper 326, Boulder, Colorado, 143-169.

Frankel, A., W.R. McCann, and A.J. Murphy (1980). Observations from a seismic network in the Virgin Islands region: tectonic structures and earthquake swarms, Bull. Seism. Soc. Am., v.85, 2669-2678.

Frankel, A., C. Mueller, T. Barnhard, D. Perkins, E. Leyendecker, N. Dickman, S. Hanson, and M. Hopper (1996). National Seismic Hazard Maps: Documentation June 1996, USGS Open-File Report 96-532, 70 pages.

Frankel, A. D., M.D. Petersen, C.S. Mueller, K.M. Haller, R.L. Wheeler, E.V. Leyendecker, R.L. Wesson, S.C. Harmsen, C.H. Cramer, D.M. Perkins, and K.S. Rukstales (2002). Documentation for the 2002 Update of theNational Seismic Hazard Maps, USGS Open-File Report 02-420, 33 pages.

Gardner, J.K., and L. Knopoff (1974). Is the sequence of earthquakes in southern California, with aftershocks removed, Poissonian?, Bull. Seism. Soc. Am., v. 64, 1363-1367.

Grindlay, N., P. Mann, and J. Dolan (1997). Researchers investigate submarine faults north of Puerto Rico, EOS, Transactions, AGU, v.78, n.38, 404.

Jansma, P.E., G.S. Mattioli, A. Lopez, C. DeMets, T.H. Dixon, P. Mann, and E. Calais (2000). Neotectonics of Puerto Rico and the Virgin Islands, northeastern Caribbean, from GPS geodesy, Tectonics, v. 6, 1021-1037.

LaForge, R.C., and W.R. McCann (2003). A seismic source model for Puerto Rico for use in probabilistic ground motion hazard analysis, submitted GSA Bulletin.

Leyendecker, E.V., R.J. Hunt, A.D. Frankel, and K.S. Rukstales (2000). Development of maximum considered earthquake ground motion maps, Earthquake Spectra, v.16, 21-40.

Masson, D.G., and K.M. Scanlon (1991). The neotectonic setting of Puerto Rico, Geol. Soc. Am. Bull., v. 103, $144-154$.

McCann, W. R. (1985). On the earthquake hazards of Puerto Rico and the Virgin Islands, Bull. Seism. Soc. Am., v.75, $251-262$.

McCann, W.R., J. Joyce, and C. Lithgow (1987). The Puerto Rico platelet at the northeastern edge of the Caribbean plate, EOS Trans. AGU, v.68, 1483.

McCann, W.R. (1993). Seismic Hazard Map for Puerto Rico, Report to The Seismic Safety Commission of Puerto Rico, 60 pages.

McCann, W.R. (1998). Tsunami hazard of western Puerto Rico from local sources: characteristics of tsunamigenic faults, Technical Report to the Department of Marine Sciences, University of Puerto Rico.

Mercado, A., and W.R. McCann (1998). Numerical simulation of the 1918 Puerto Rico tsunami, Natural Hazards, v.18, 57-76.

Motazedian, D., and G. Atkinson (2003). Ground motion relations for Puerto Rico, submitted GSA Bulletin.

Mueller, C., M. Hopper, and A. Frankel (1997). Preparation of earthquake catalogs for the national seismic hazard maps: contiguous 48 states, USGS Open-File Report 97-464, 36 pages.

Prentice, C.S., P. Mann, F.W. Taylor, G. Burr, and S. Valastro (1993). Paleoseismicity of the North American Caribbean plate boundary (Septentrional fault), Dominican Republic, Geology, v. 21, 49-52.

Prentice, C.S., P. Mann, P., and G. Burr (2000). Prehistoric earthquakes associated with a Late Quaternary fault in the Lajas Valley, southwestern Puerto Rico, EOS, Transactions of the American Geophysical Union, v. 81, F1182 (abstract).

Prentice, C.S., P. Mann, L.R. Pena, and G. Burr (2003). Slip rate and earthquake recurrence along the central Septentrional fault, North American - Caribbean plate boundary, Dominican Republic, in press Jour. Geophys. Res.

Sadigh, K., C.-Y. Chang, J.A. Egan, F. Makdisi, R.R. Youngs (1997). Attenuation relationships for shallow crustal earthquakes based on California strong motion data, Seism. Res. Letts., v. 68, 180-189.

Spudich, P., W.B. Joyner, A.G. Lindh, D.M. Boore, B.M. Margaris, and J.B. Fletcher (1999). SEA99: A revised ground motion prediction relation for use in extentional tectonic regimes, Bull. Seism. Soc. Am., v. 89, 1156-1170.

Weichert, D.H. (1980). Estimation of earthquake recurrence parameters for unequal observation periods for different magnitudes, Bull. Seism. Soc. Am., v. 70, 1337-1356.

Wells, D.L., and K.J. Coppersmith (1994). New empirical relationships among magnitude, rupture length, rupture width, rupture area, and surface displacement, Bull. Seism. Soc. Am., v.84, 974-1002. 
Youngs, R.R., S.-J. Chiou, W.J. Silva, and J.R. Humphrey (1997). Strong ground motion attenuation relationships for subduction zone earthquakes Seism. Res. Letts., v. 68, 58-73.

Wessel, P. and W. H. F. Smith (1991). Free software helps map and display data, EOS Trans. AGU, 72, 441 \& 445-446.

\section{Figure Captions}

Figure 1. Map of North American-Caribbean plate boundary region. Inset box shows area of seismic hazard analysis. Arrow shows motion of North American plate relative to Caribbean plate from Jansma et al. (2000). Structural elements generalized from Grindlay et al. (1997), Dolan et al. (1998), and La Forge and McCann (2003). Abbreviations: H=Hispaniola, PR=Puerto Rico, VI=Virgin Islands, PT=Puerto Rico Trench, MT=Muertos Trough, MP=Mona Passage, AP=Anegada Passage.

Figure 2 Map showing modeled seismic hazard sources. Diagonal pattern=subduction segments (sparse=Puerto Rico seg., dense=Hispaniola seg.). Vertical pattern=Mona and Andegada extensional zones. SF=Septentrional fault. SPRSFZ=South Puerto Rico Slope fault zone. SLF=Sough Lajas fault. Abbreviations: H=Hispaniola, PR=Puerto Rico, V=Vieques, C=Culebra, SC=St. Croix, ST=St. Thomas, SJ=St. John.

Figure 3a. PGA $(\% \mathrm{~g})$ with $2 \%$ probability of exceedance in 50 years from shallow seismicity $(\mathrm{d}<50 \mathrm{~km})$.

Figure 3b. PGA $(\% \mathrm{~g})$ with $2 \%$ probability of exceedance in 50 years from deep seismicity $(\mathrm{d}>=50 \mathrm{~km})$.

Figure 3c. PGA $(\% \mathrm{~g})$ with $2 \%$ probability of exceedance in 50 years from Puerto Rico subduction.

Figure 3d. PGA $(\% \mathrm{~g})$ with $2 \%$ probability of exceedance in 50 years from Hispaniola subduction.

Figure 30. PGA $(\% \mathrm{~g})$ with $2 \%$ probability of exceedance in 50 years from Anegada and Mona extensional zones.

Figure 4. PGA (\%g) with $2 \%$ probability of exceedance in 50 years from all modeled sources.

Figure 5. 1.0-sec spectral acceleration $(\% \mathrm{~g})$ with $2 \%$ probability of exceedance in 50 years from all modeled sources.

Figure 6. $0.2-\mathrm{sec}$ spectral acceleration $(\% \mathrm{~g})$ with $2 \%$ probability of exceedance in 50 years from all modeled sources.

Figure 7. PGA $(\% \mathrm{~g})$ with $10 \%$ probability of exceedance in 50 years from all modeled sources.

Figure 8. 1.0-sec spectral acceleration $(\% \mathrm{~g})$ with $10 \%$ probability of exceedance in 50 years from all modeled sources.

Figure 9. 0.2-sec spectral acceleration $(\% \mathrm{~g})$ with $10 \%$ probability of exceedance in 50 years from all modeled sources.

Figure 10. PGA $(\% \mathrm{~g})$ with $2 \%$ probability of exceedance in 50 years from all modeled sources. Compare $9-\mathrm{mm} / \mathrm{yr}$ (top) and 1-mm/yr (bottom) scenarios for South Puerto Rico Slope fault zone (440-year and 3900-year recurrence, respectively).

Figure 11. $0.2-\mathrm{sec}$ spectral acceleration $(\% \mathrm{~g})$ with $2 \%$ probability of exceedance in 50 years from all modeled sources. Compare $50 \%$ (top) and $10 \%$ (bottom) weights for Motazedian \& Atkinson (2003) attenuation.

Figure 12 1.0-sec spectral acceleration $(\% \mathrm{~g})$ with $2 \%$ probability of exceedance in 50 years from all modeled sources. Compare $50 \%$ (top) and $10 \%$ (bottom) weights for Motazedian \& Atkinson (2003) attenuation.

Figure 13a. PGA hazard curves for San Juan.

Figure 13b. PGA hazard curves for Mayaguez.

Figure 13c. PGA hazard curves for Ponce.

Figure 13d. PGA hazard curves for Charlotte Amalie.

Figure 130. PGA hazard curves for Christiansted. 
Figure 13f. PGA hazard curves for southwest Puerto Rico $(18.0,-67.0)$. 